\title{
ELEMEN PEMBENTUK CITRA KAWASAN BERSEJARAH DI PUSAT KOTA MALANG
}

\author{
Hana Ayu Pettricia, Dian Kusuma Wardhani, Antariksa \\ Jurusan Perencanaan Wilayah dan Kota Fakultas Teknik Universitas Brawijaya \\ e-mail: dkwardhani@yahoo.com
}

\begin{abstract}
ABSTRAK
Studi mengenai citra suatu kawasan perlu dilakukan untuk mengetahui identitas kawasan. Kecamatan Klojen merupakan kawasan yang memiliki peninggalan bangunan dan lingkungan bersejarah pada jaman Kolonial Belanda, oleh karena itu perlu dilakukan studi mengenai citra kawasan bersejarah di Kecamatan Klojen. Tujuan dari studi ini adalah menganalisis elemen-elemen pembentuk citra kawasan bersejarah di Kecamatan Klojen berdasarkan persepsi penduduk Kota Malang. Persepsi penduduk Kota Malang dibagi menjadi tiga golongan, yaitu golongan masyarakat, mahasiswa, dan ahli. Metode penelitian yang digunakan adalah analisis deskriptif. Metode deskriptif digunakan untuk menganalisis elemen-elemen pembentuk citra kawasan, dengan menggunakan peta mental dan wawancara. Hasil studi adalah (1) elemen pembentuk citra bersejarah di pusat kota yaitu elemen path (Jl Kayutangan-Jl Pasar Besar), elemen node (Perempatan Kayutangan dan Kawasan Alun-Alun Merdeka), dan elemen landmark (Alun-Alun Tugu dan Masjid Jami'); (2) Kecamatan Klojen sudah dapat disebut dengan place karena identitas dari masing-masing elemen telah dikenal oleh lebih dari 50\% penduduk Kota Malang.
\end{abstract}

Kata Kunci: citra, bersejarah, teori gestalt, peta mental.

\begin{abstract}
The study of the image of an area needs to be done to find out the identity of the place. District of Klojen is an area that has a legacy of historic buildings and environment in the Dutch colonial era, therefore it is necessary to study the image of the District Klojen kawasan bersejarah.This study aims: (1) analyze the imageforming elements in the historic district based on the perception of residents Klojen District of Malang, and (2) analyze the factors that influence respondents in identifying the image-forming elements in the historic district Klojen. Malang resident perception is divided into three groups, ie community groups, students, and experts. The method are used descriptive analytical and evaluative analysis. Descriptive methods isused to analyze the elements of the image forming region, using mental maps and interviews. Evaluative analysis used to analyze the factors that influence respondents to identify the image of the historic district, and to review the typology of perception of the respondents use the gestalt theory. The results are (1) image of the historic downtown district that is Klojen still can't properly captured by the inhabitants of the city of Malang, and the District Klojen still highlight the historic image, (2) factors that influence respondents' perceptions are internal factors and external. Typology of perception, internal factors and external factors had ties in identifying the image of the historic district.
\end{abstract}

Key words: image, historic, gestalt theory, mental maps. 


\section{Pendahuluan}

Kota Malang merupakan salah satu hasil perencanaan kota kolonial yang terbaik di Hindia Belanda. Hal ini dapat dilihat dari banyaknya peninggalan arsitektur kolonial yang hingga saat ini masih berdiri megah (Handinoto, 2010:236) dan tata lingkungan yang mempunyai nilai historis. Peninggalan arsitektur dan tata lingkungan Kota Malang ini menjadi bukti perkembangan Malang yang tumbuh dengan pesat dari sebuah kabupaten kecil, menjadi sebuah kotamadya kedua terbesar di Jawa Timur yaitu antara tahun 1914-1940.

Citra terhadap suatu kota berkaitan erat dengan identitas dari beberapa elemen dalam suatu kota yang berkarakter dan khas sebagai jati diri yang dapat membedakan dengan kota lainnya (Purwanto, 2001). Penelitian tentang citra kawasan sangat penting untuk mengetahui apakah produk rancangan suatu kawasan berhasil atau tidak berhasil dipahami oleh masyarakat luas.

Citra kawasan bersejarah dilakukan dengan menggunakan persepsi penduduk Kota Malang melalui peta mental. Penduduk Kota Malang digunakan sebagai penilai citra kawasan bersejarah karena telah mengetahui kondisi lingkungan Kota Malang. Pusat Kota Malang, yaitu Kecamatan Klojen dipilih menjadi wilayah studi penelitian karena kawasan ini dari masa Kolonial Belanda hingga sekarang merupakan pusat kegiatan yang sangat berpengaruh bagi perkembangan Kota Malang. Pusat kota, yaitu Kecamatan Klojen juga dapat menjadi identitas dari Kota Malang sebagai kota yang memiliki nilai sejarah. Berdasarkan latar belakang di atas, maka permasalahan studi ini adalah bagaimana elemen-elemen pembentuk citra kawasan bersejarah di Kecamatan Klojen berdasarkan penduduk Kota Malang.

\section{Bahan dan Metode}

Metode penelitian menggunakan analisis deskriptif dan analisis evaluatif. Analisis deskriptif digunakan untuk menjawab elemen-elemen pembentuk citra kawasan bersejarah di Kecamatan Klojen. Cara yang dilakukan untuk memperoleh elemenelemen tersebut adalah dengan peta mental dan wawancara. Metode dari peta mental yang dipilih adalah dengan menggunakan Sketch Maps (Bell, 2001).

Analisis evaluatif yang digunakan untuk menjawab faktor-faktor apa saja yang mempengaruhi responden dalam mengidentifikasi elemen-elemen Citra Kawasan Bersejarah di Kecamatan Klojen.

Tipologi persepsi ditinjau dari teori Gestalt (Halim, 2005:162). Untuk mengetahui faktor yang mempengaruhi persepsi dalam mengidentifikasi elemenelemen Citra Kawasan Bersejarah menggunakan analisis faktor konfirmatori (Munir, 2005), dan Model Miles dan Huberman (Sugiyono, 2011).

Penentuan sampel dibagi menjadi 3 golongan, yaitu golongan masyarakat, mahasiswa, dan ahli.

a. Kelompok ahli: ahli sejarah, ahli arsitektur, ahli tata kota (PWK), dan pemerintahan. Jumlah sampel adalah 8 responden;

b. Kelompok mahasiswa: mahasiswa tingkat akhir di Kota Malang dengan jurusan arsitektur dan PWK. Jumlah sampel adalah 64 responden; dan

c. Masyarakat umum: Penduduk yang tinggal di Kota Malang minimal 1 tahun. Umur masyarakat umum yang bertempat tinggal berkisar antara 15-69 tahun. Jumlah sampel adalah 72 responden. 


\section{Hasil Dan Pembahasan}

3.1. Citra Kawasan Kota Malang Hingga 1935 (Tabel 1)

Tabel 1. Citra Kawasan Kota Malang Hingga 1935

\begin{tabular}{|c|c|c|}
\hline No. & Elemen & Name \\
\hline 1. & Path & $\begin{array}{l}\text { - Jl Letjen Sutoyo } \\
\text { - Kayutangan } \\
\text { - Jl Merdeka Utara } \\
\text { - Jl Merdeka Timur } \\
\text { - Jl SW. Pranoto } \\
\text { - Jl Pasar Besar } \\
\text { - Jl Ijen } \\
\text { - Jl Kertanegara-Jl Semeru } \\
\text { - Oro-oro Dowo } \\
\text { - Jl Kawi }\end{array}$ \\
\hline 2. & Node & $\begin{array}{l}\text { - Alun-alun Merdeka } \\
\text { - Alun-alun Tugu } \\
\text { - Chinatown } \\
\end{array}$ \\
\hline 3. & District & $\begin{array}{l}\text { - } \text { Chinatown } \\
\text { - Kayutangan } \\
\text { - Arabian people area } \\
\text { - Oranjebuurt } \\
\text { - Sukun graveyard } \\
\text { - Celaket dan Lowokwaru } \\
\text { - } \text { (pribumi) } \\
\text { - Eurgenbuurt } \\
\text { - Induandenbuurt } \\
\end{array}$ \\
\hline 4. & Landmark & $\begin{array}{l}\text { - Alun-alun Tugu } \\
\text { - Town Hall } \\
\text { - Masjid Jami' } \\
\text { - Gereja Hati Kudus } \\
\text { - Gedung PLN } \\
\text { - Cor Jesu } \\
\text { - Frateran } \\
\text { - Stasiun Kota Baru }\end{array}$ \\
\hline 5. & Edge & $\begin{array}{l}\text { - Sungai Brantas } \\
\text { - Jl Gatot Subroto } \\
\text { - Jl Kawi }\end{array}$ \\
\hline
\end{tabular}




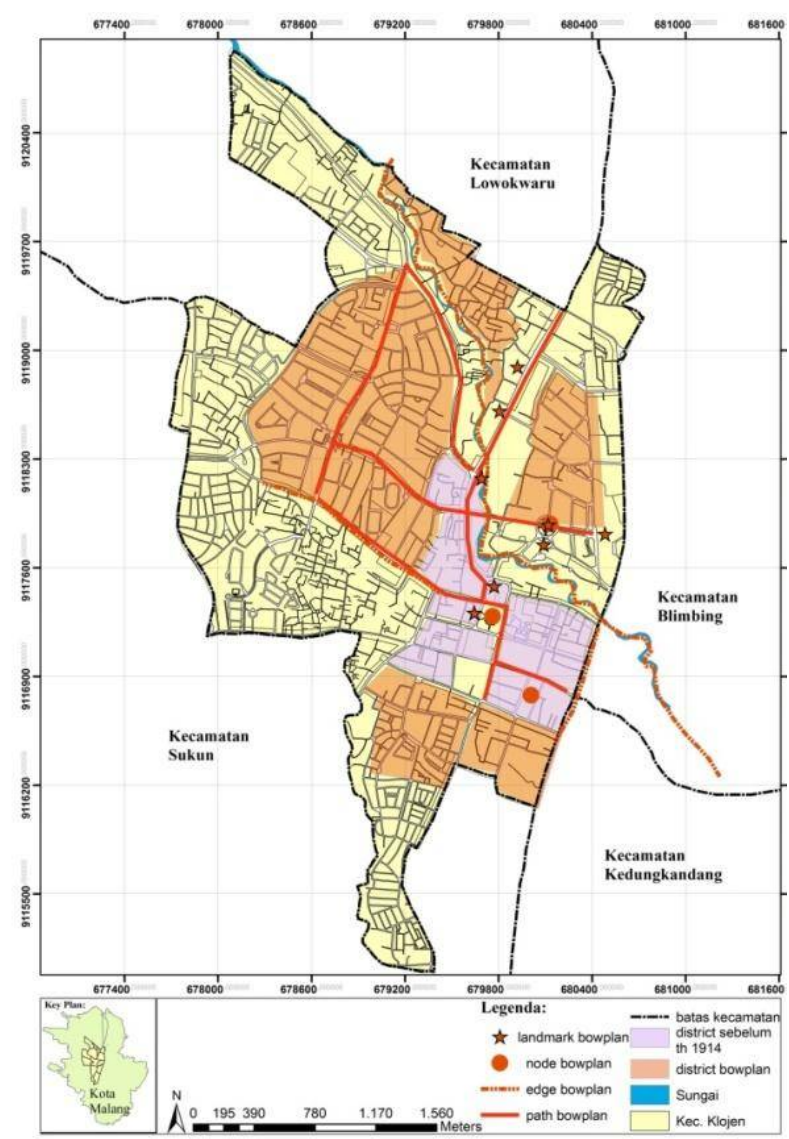

Gambar 1. Citra Kawasan Kota Malang Hingga 1935

\subsubsection{Citra kawasan bersejarah menurut masyarakat}

Berdasarkan hasil survei primer kepada masyarakat mengenai elemen-elemen pembentuk citra kawasan bersejarah di Kecamatan Klojen, maka dapat disimpulkan bahwa kelima elemen citra kawasan telah terbentuk. Kelima elemen citra kawasan tersebut terdiri dari bangunan, ruang terbuka, dan jalan (Tabel 2)

Tabel 2. Citra Kawasan Bersejarah Menurut Masyarakat

\begin{tabular}{|c|c|c|}
\hline No. & Element & Name \\
\hline 1. & Path & $\begin{array}{ll}\text { - } & \text { Kayutangan } \\
\text { - } & \text { Jl Merdeka Utara } \\
\text { - } & \text { Jl Merdeka Timur } \\
\text { - } & \text { Jl SW. Pranoto } \\
\text { - } & \text { Jl Pasar Besar } \\
\text { - } & \text { Jl Ijen }\end{array}$ \\
\hline 2. & Node & $\begin{array}{ll}\text { - } & \text { Alun-alun Merdeka } \\
\text { - } & \text { Kayutangan Crossroad }\end{array}$ \\
\hline 3. & District & - Jl Ijen District \\
\hline 4. & Landmark & $\begin{array}{ll}\text { - } & \text { Jami Mosque } \\
\text { - } & \text { Alun-alun Tugu } \\
\text { - } & \text { Town Hall }\end{array}$ \\
\hline 5. & Edge & - Jl Ijen \\
\hline
\end{tabular}


Tipologi penggamabaran peta mental yang dibuat oleh masyarakat tidak semua elemen digambarkan. Elemen yang sering digambarkan adalah path, node, dan landmark, hal ini disebabkan karena ketiga elemen ini mudah dilihat dan diidentifikasi. Elemen-elemen yang disebutkan oleh masyarakat secara keseluruhan merupakan kawasan yang terletak di jalan utama. Hal ini dapat dilihat dari elemen path adalah Jalan Kayutangan yang menuju ke Kawasan Alun-Alun Merdeka sebagai CBD (elemen node) Disekitar Kawasan Alun-Alun Merdeka terdapat bangunan yang paling diingat masyarakat, yaitu Masjid Jami' (landmark). Jl Ijen juga memiliki peranan penting dalam memberikan citra bersejarah di Kecamatan Klojen, hal ini dapat dilihat dari munculnya kawasan Jl Ijen sebagai elemen district dan edge.

Jika ditinjau dari kelima elemen citra kawasan yang telah disebutkan oleh masyarakat, terdapat hubungan antara elemen landmark dan elemen node. Bangunanbangunan yang mudah diingat oleh masyarakat terletak di kawasan pusat kegiatan. Elemen path, elemen edge, dan elemen district juga memiliki hubungan. Elemen path yang dominan menjadi dasar masyarakat untuk menentukan elemen district dan edge, hal ini dapat dilihat dari munculnya Jl Ijen sebagai path serta edge dan kawasan di Jl Ijen menjadi elemen district yang paling dikenal (Gambar 2).

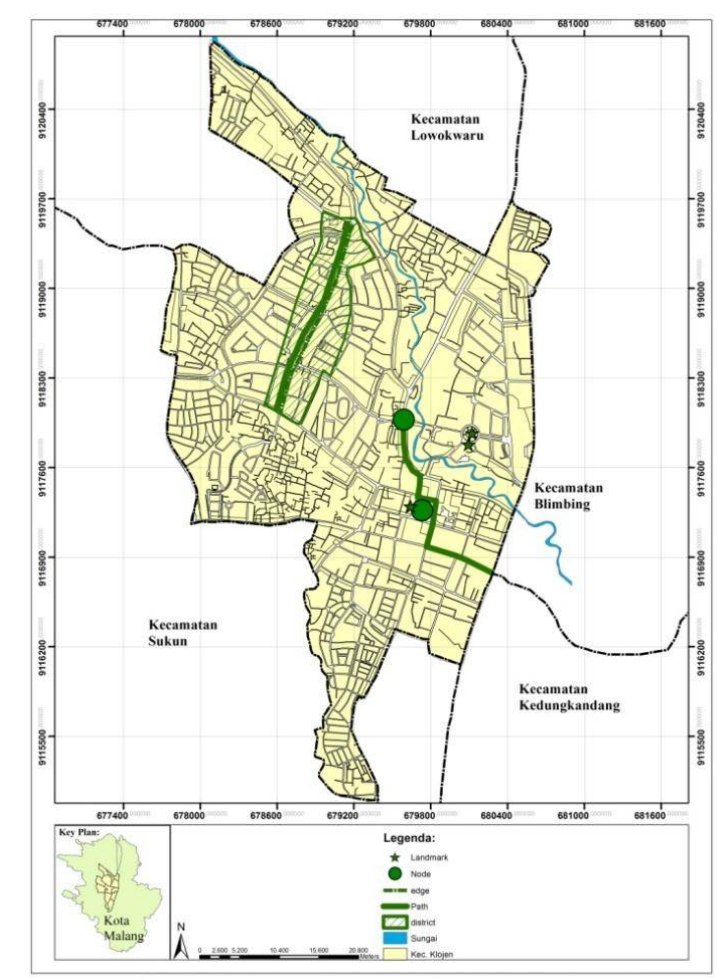

Gambar 2. Citra Kawasan Bersejarah Menurut Masyarakat

\subsubsection{Citra kawasan bersejarah menurut mahasiswa}

Tabel 3. Citra Kawasan Bersejarah Menurut Mahasiswa

\begin{tabular}{|c|c|c|}
\hline No. & Elemen & Nama \\
\hline 1. & Path & $\begin{array}{ll}\text { - } & \text { Jl Pasar Besar } \\
\text { - } & \text { Jl SW. Pranoto } \\
\text { - } & \text { Jl Merdeka Timur } \\
\text { - } & \text { Jl Merdeka Utara } \\
\text { - } & \text { Jl Kayutangan } \\
\text { - } & \text { Jl Kertanegara }\end{array}$ \\
\hline
\end{tabular}




\begin{tabular}{|c|c|c|}
\hline No. & Elemen & Nama \\
\hline 2. & Node & $\begin{array}{ll}\text { - } & \text { Alun-alun Merdeka } \\
\text { - } & \text { Kayutangan Crossroad } \\
\text { - } & \text { Alun-alun Merdeka Crossroad }\end{array}$ \\
\hline 3. & District & $\begin{array}{l}\text { - Kayutangan } \\
\text { - Chinatown }\end{array}$ \\
\hline 4. & Landmark & $\begin{array}{ll}\text { - } & \text { Gereja GPIB } \\
\text { - } & \text { Masjid Jami' } \\
\text { - } & \text { Kantor pos } \\
\text { - } & \text { Alun-alun Tugu } \\
\end{array}$ \\
\hline 5. & Edge & - Jl Kawi \\
\hline
\end{tabular}

Pada Tabel 3 Dapat disimpulkan bahwa kelima elemen citra kawasan telah digambarkan pada peta mental mahasiswa, hal ini berkaitan dengan ilmu yang telah diperoleh mengenai citra kawasan. Tipologi peta mental yang digambarkan oleh mahasiswa cenderung di kawasan pusat perdagangan dan jasa, yaitu Kawasan Alun-alun Merdeka. Selain Alun-Alun Merdeka, Jalan Kayutangan juga menjadi elemen district paling dominan, karena kawasan ini memiliki karakter khusus yang mudah dikenal, yaitu kawasan pertokoan dengan permukiman dibelakangnya. Masjid Jami' menjadi elemen landmark paling dominan karena karakteristik fisiknya sangat berbeda dari lingkungan sekitarnya. Elemen edge yang disebutkan mahasiswa adalah Jl Kawi, karena jalan ini merupakan batas antara kawasan perdagangan dengan kawasan permukiman.

Jika ditinjau secara keseluruhan, terdapat hubungan antara elemen node dan landmark. Hal ini dapat dilihat dari persebaran elemen landmark terdapat di kawasan pusat kegiatan. Elemen path dan district juga memiliki hubungan pada persepsi mahasiswa. Munculnya kawasan Kayutangan dan kawasan Pecinan sebagai district dapat dipengaruhi oleh munculnya jalan Jl Kayutangan-Jl Pasar Besar sebagai elemen path (Gambar 3).

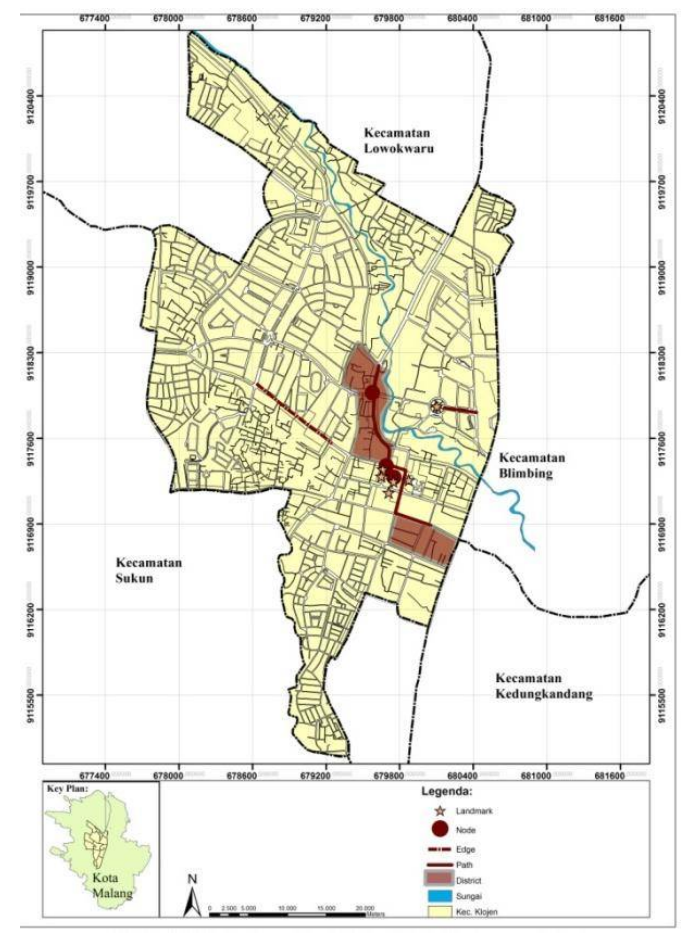

Gambar 3. Citra Kawasan Bersejarah Menurut Mahasiswa 


\subsubsection{Citra kawasan bersejarah berdasarkan persepsi para ahli}

Kelompok ahli merupakan kelompok yang sangat menguasai dan memahami mengenai citra kawasan dan sejarah Kota Malang. Kelompok ahli yang dipilih adalah ahli arsitektur, ahli perencana, ahli sejarah, dan penentu kebijakan. Berdasarkan hasil survey kelompok ahli, diperoleh kesimpulan bahwa elemen citra kawasan diu Kecamatan Klojen yang masih memiliki nilai sejarah (Tabel 4)

Tabel 4. Citra Kawasan Bersejarah berdasarkan Persepsi Para Ahli

\begin{tabular}{lll}
\hline No. & Elemen & Nama \\
\hline 1. & Path & Jl Kayutangan-Jl Pasar Besar \\
& & Jl Kertanegara-Jl Semeru \\
& Jl Ijen \\
& & Oro-oro Dowo \\
& & Jl Kawi \\
& & Alun-alun Merdeka \\
& & Alun-alun Tugu \\
& Node & Perempatan Kayutangan \\
& & Jalan gunung-gunung \\
3 & Jistrict & Jalan pulau-pulau \\
& & Pecinan \\
& & Stasiun Kota Baru \\
4 & Landmark & Tugu and Balai Kota Malang \\
& & Gereja Hati Kudus \\
& & Masjid Jami \\
& & Gedung Sekolah Cor Jesu \\
& & Gedung PLN \\
& & Sungau Brantas \\
5 & Edge & Jl Kawi \\
& & Jl Gatot Subroto \\
\hline
\end{tabular}

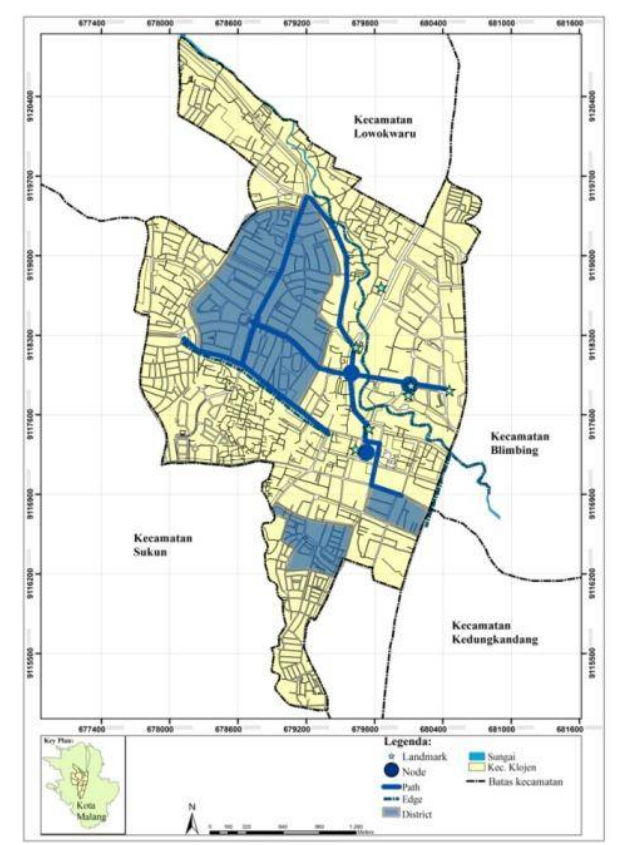

Gambar 4. Citra Kawasan Bersejarah Menurut Para Ahli 


\subsubsection{Kesamaan persepsi dari masyarakat, mahasiswa, dan para ahli}

Beberapa kesamaan persepsi dari ketiga golongan adalah Jl Pasar Besar-Jl Kayutangan sebagai elemen path (61\%); kawasan Alun-Alun Merdeka (72\%), dan perempatan Kayutangan (63\%) sebagai elemen node; serta Masjid Jami' (62\%) dan Alun-Alun Tugu (53\%) sebagai elemen landmark. Besarnya prosentase kemunculan yang melebihi rata-rata dari jumlah total responden penduduk Kota Malang $(>50 \%)$ dapat disimpulkan bahwa Kecamatan Klojen telah disebut dengan place, karena telah member karakter yang spesifik yaitu sebagai kawasan bersejarah jaman Kolonial Belanda. Berdasarkan Teori Lynch, karakter yang spesifik dapat membentuk suatu identitas, yang merupakan suatu pengenalan dan kualitas ruang sebuah daerah perkotaan, yang secara umum disebut a sense of place.

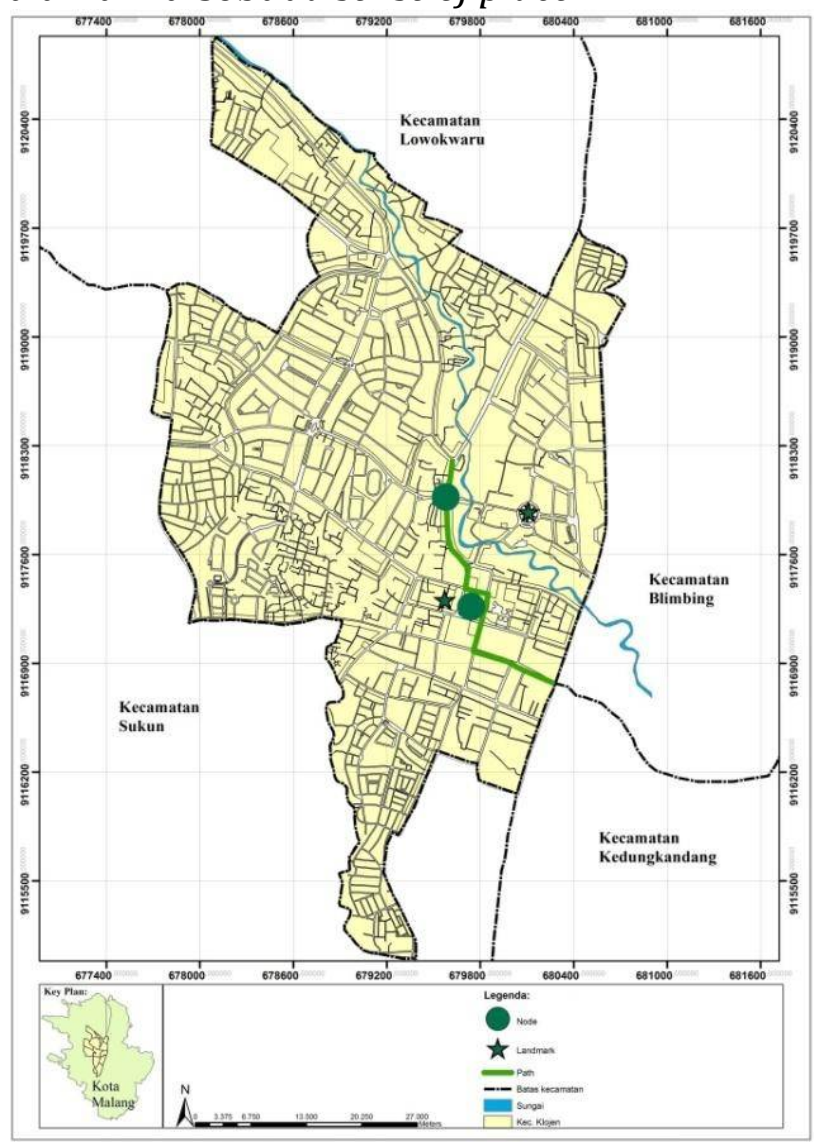

\section{Gambar 5. Elemen Pembentuk Citra Kawasan Bersejarah}

\subsection{Tipologi Persepsi berdasarkan Teori Gestalt}

Tipologi persepsi dilakukan untuk mengevaluasi hasil dari elemen citra kawasan bersejarah di Kecamatan Klojen. Evaluasi elemen yang menggunakan teori Gestalt memudahkan untuk mengidentifikasi Citra Kawasan oleh penduduk Kota Malang. Penjelasan tipologi persepsi berdasarkan pada Citra Kawasan yaitu path, node, district, landmark, dan edge (Gambar 6-11). 


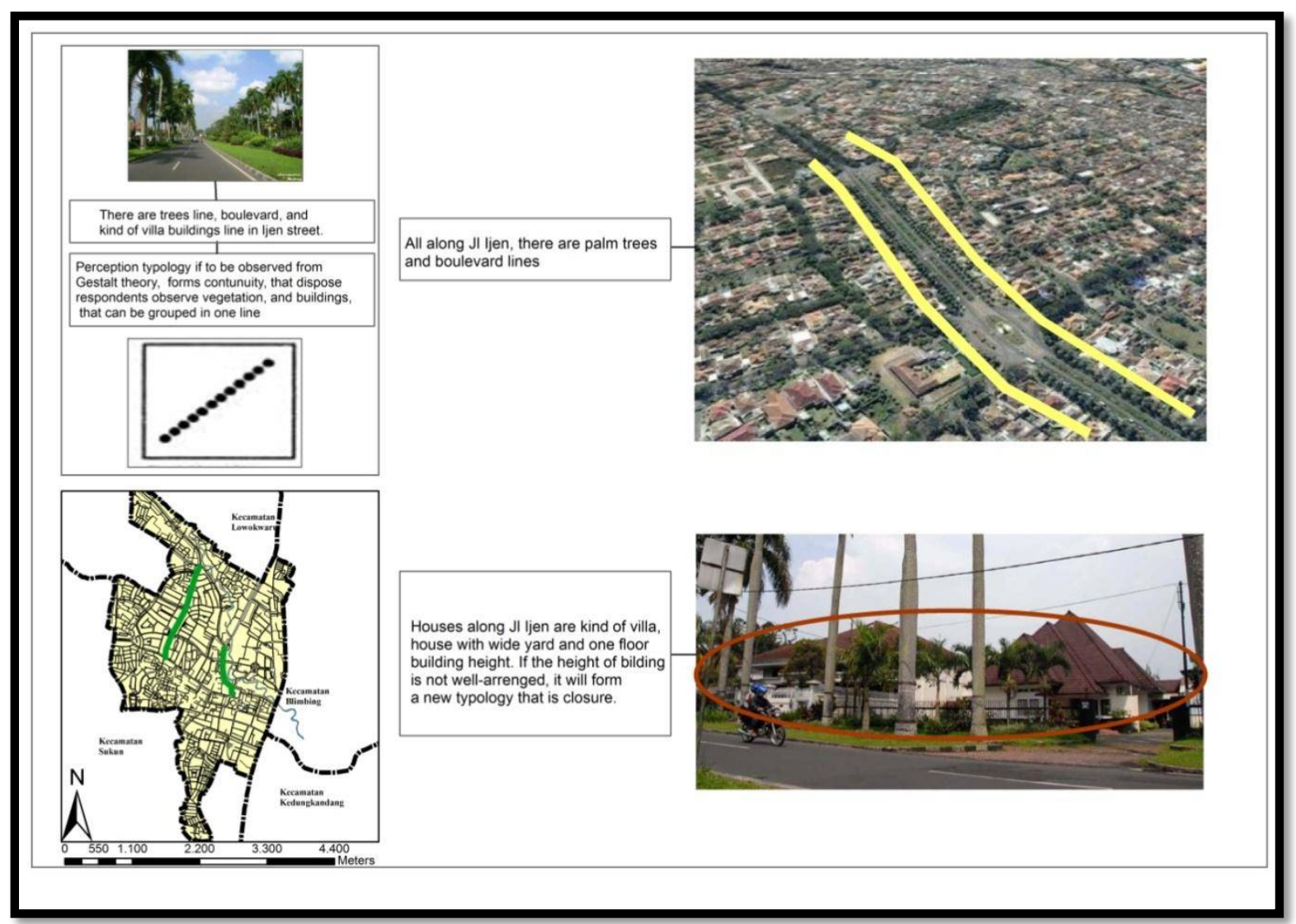

Gambar 6. Tipologi Persepsi tentang Elemen Path

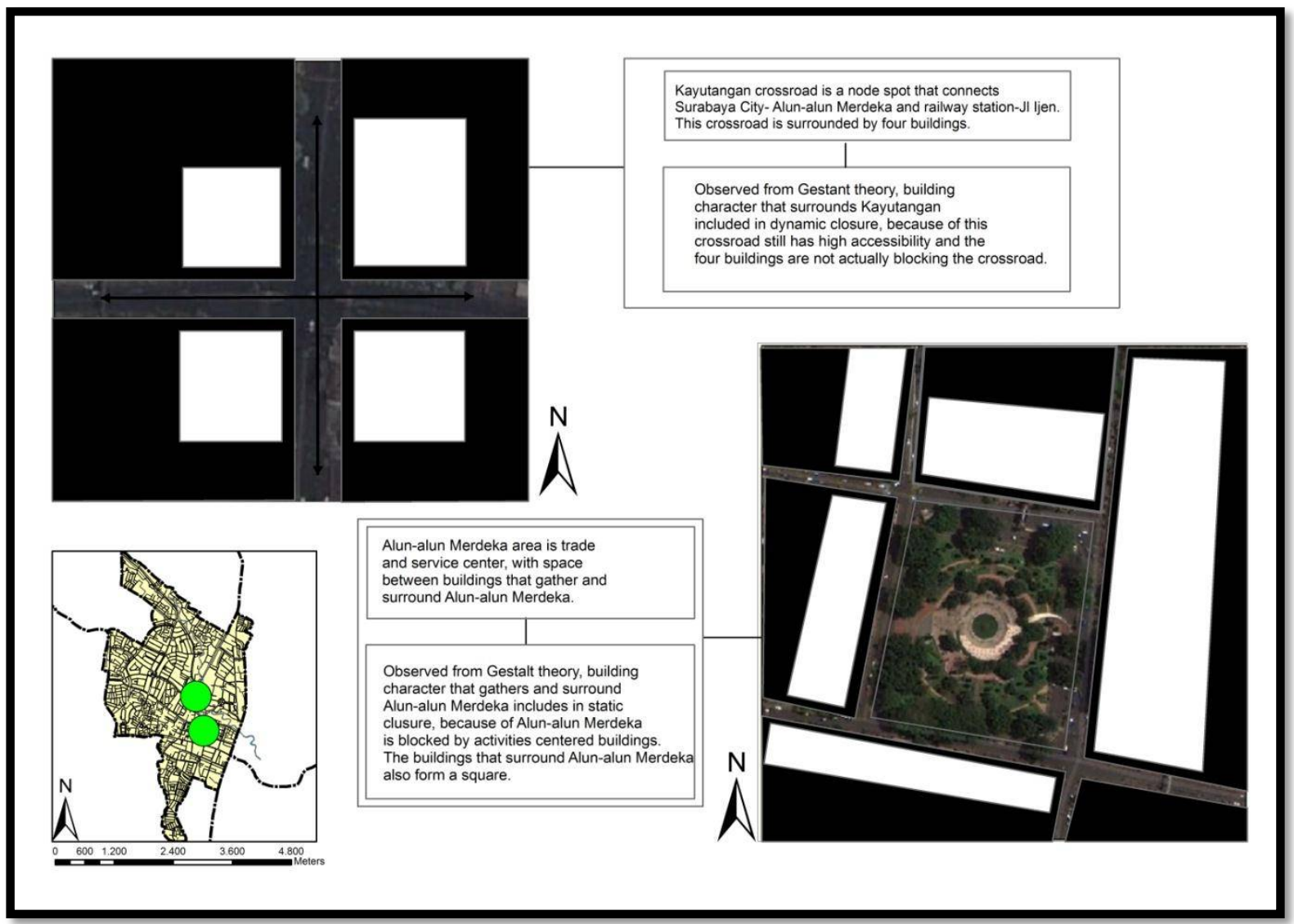

Gambar 7. Tipologi Persepsi tentang Elemen Node 


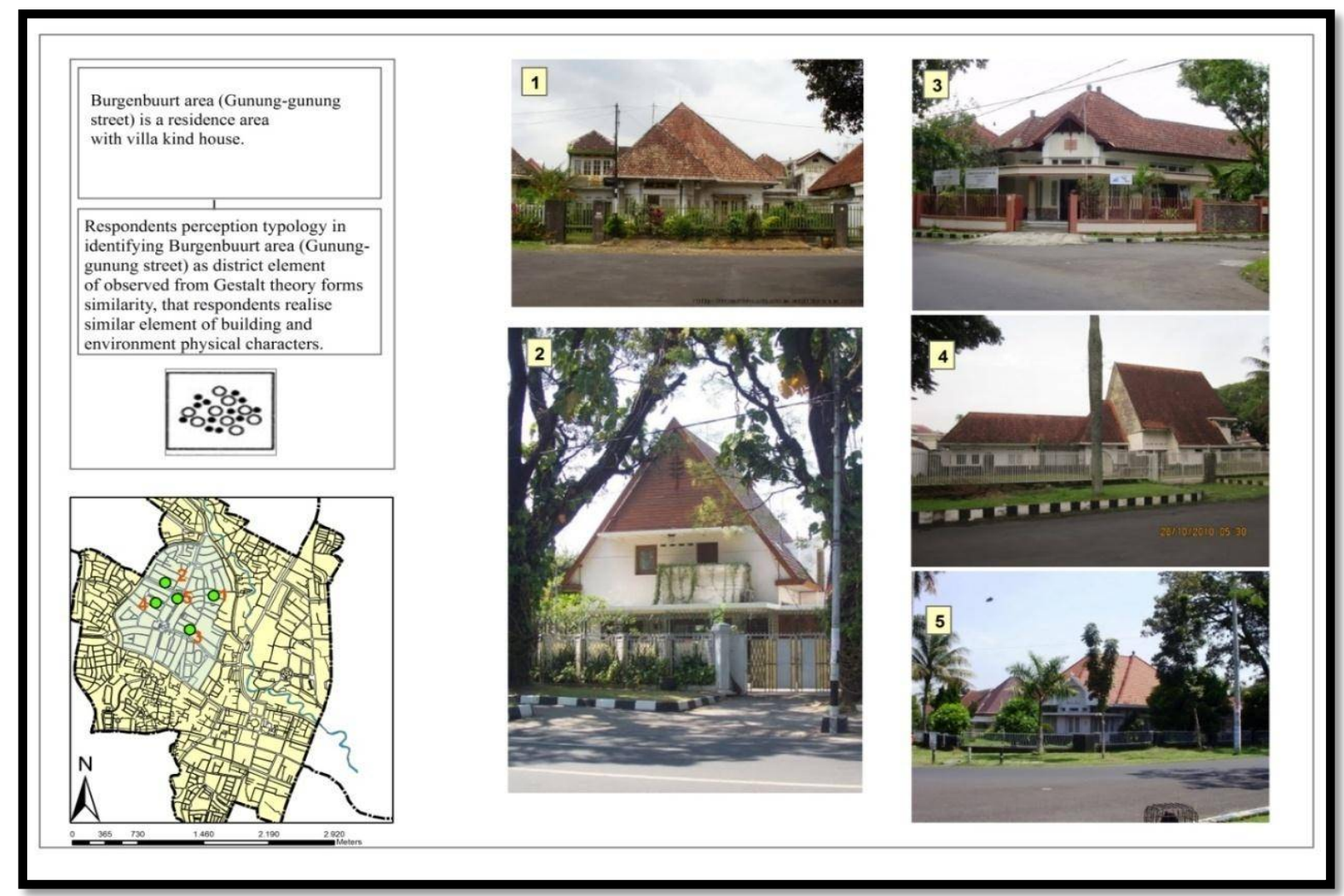

Gambar 8. Tipologi Persepsi tentang Elemen District (Bangunan di Jalan GunungGunung)

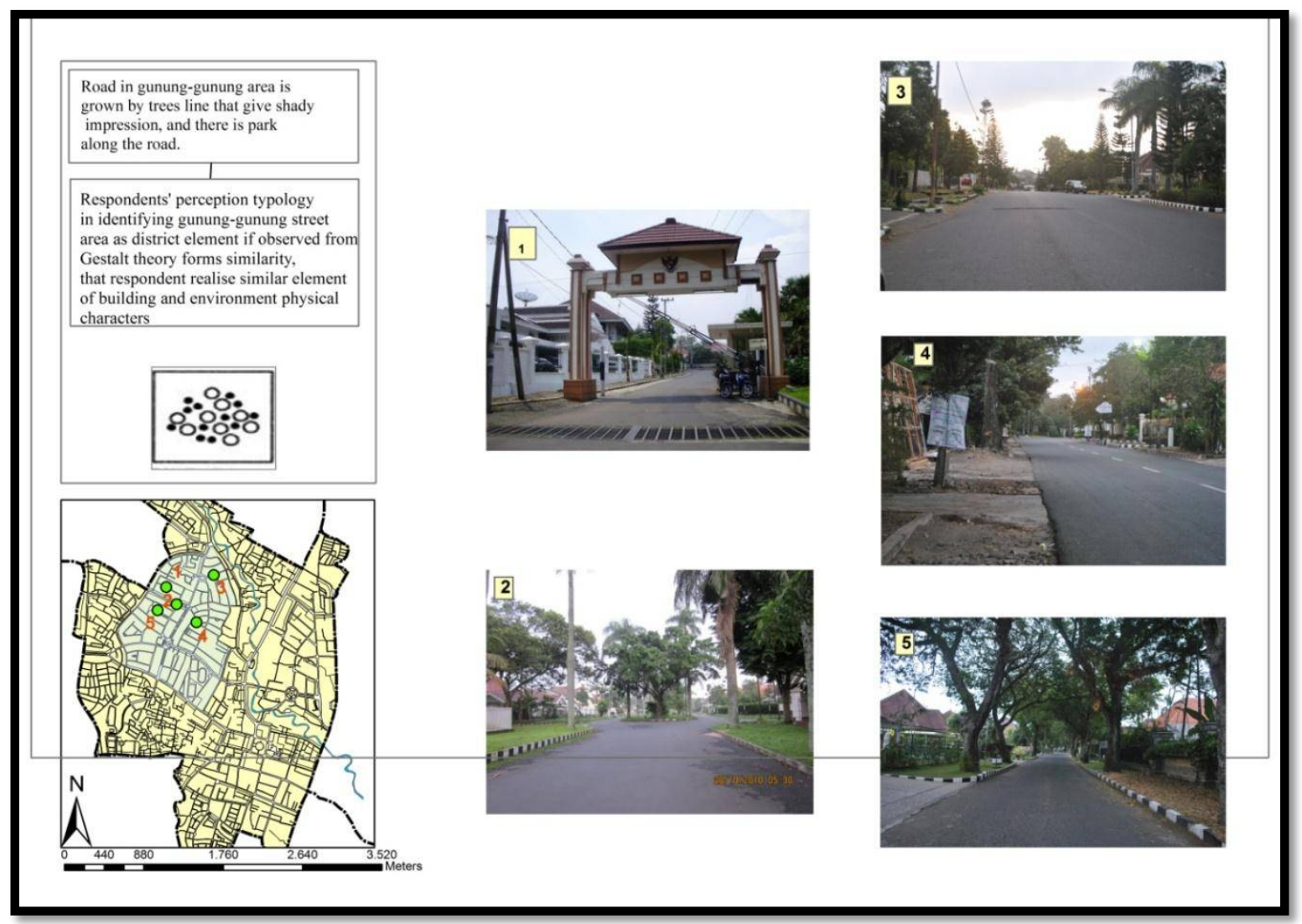

Gambar 9. Tipologi Persepsi tentang Elemen District (Lingkungan di Jalan Gunung-Gunung) 


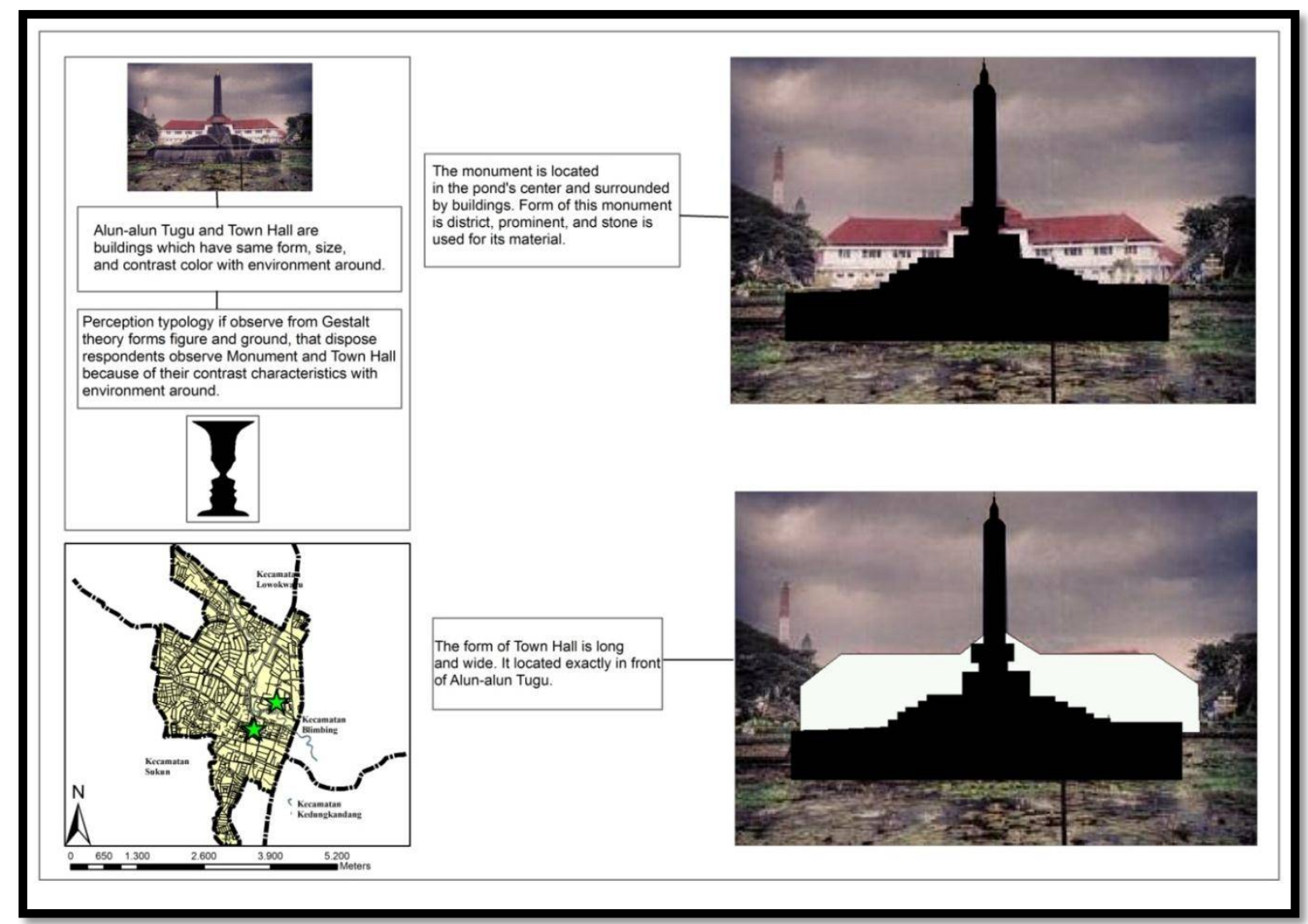

Gambar 10. Tipologi Persepsi tentang Elemen Landmark

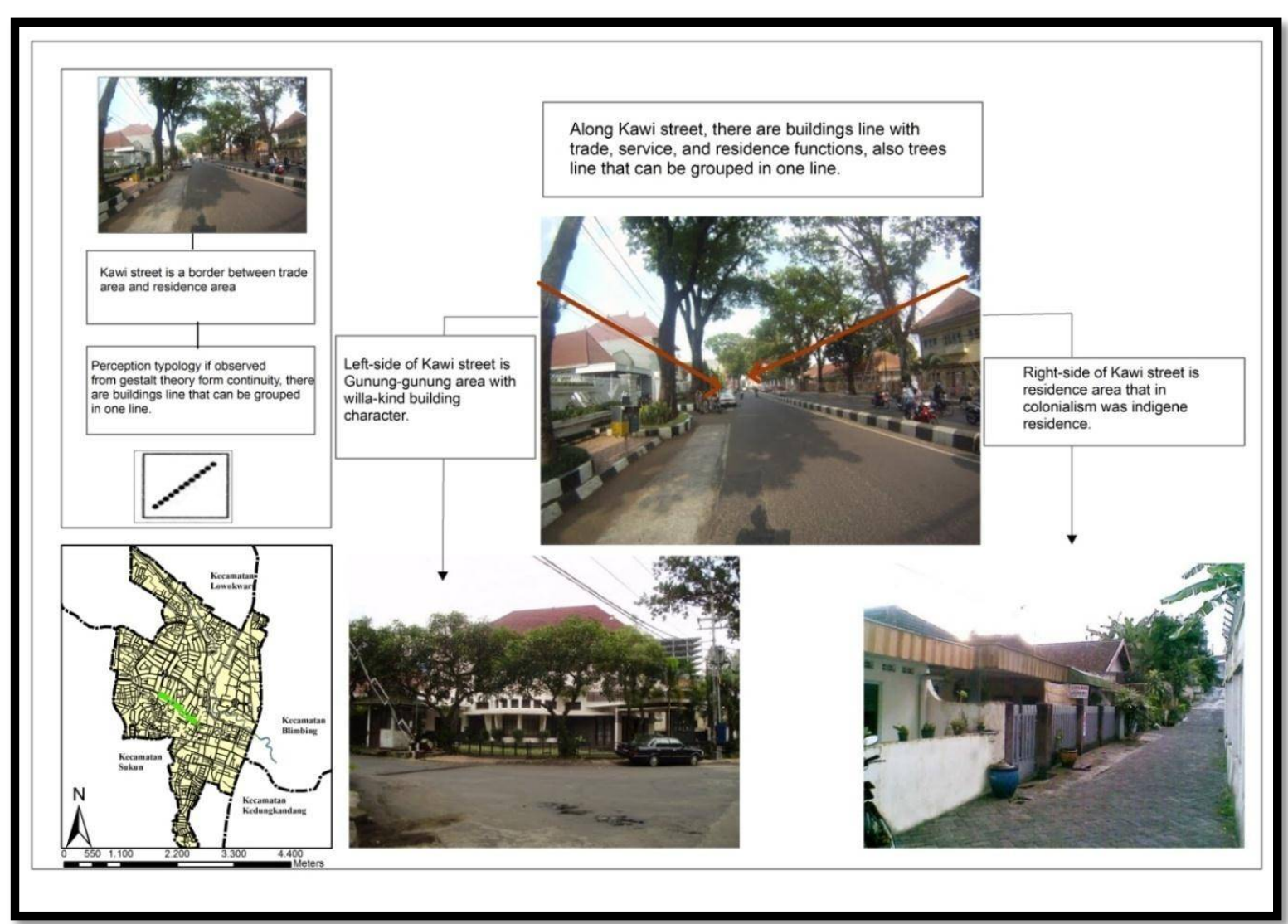

Gambar 11. Tipologi Persepsi tentang Elemen Edge 


\subsubsection{Faktor yang mempengaruhi responden}

Dasar penentuan faktor dan variabel untuk analisis faktor konfirmatori adalah berdasarkan teori dan penelitian terdahulu. Analisis faktor adalah untuk masyarakat dan golongan mahasiswa, dan interview untuk golongan ahli.

Table 5. Faktor dan Variabel yang digunakan untuk Analisis Konfirmatori

\begin{tabular}{llll}
\hline No & Faktor & \multicolumn{2}{c}{ Variabel } \\
\hline 1 & Internal & - & Keakraban dengan kondisi \\
& & lingkungan (Sarwono,1992) \\
& & Pembelajaran persepsi (Halim, \\
& & 2005) \\
& & Motivasi dan kebutuhan (Halim, \\
& & 2005) \\
& Eksternal & - & Kekuatan tujuan (Damayanti, \\
& & 2005) \\
& & Posisi objek (Sarwono, 1992) \\
& & Warna (Ikhsan, 2002) \\
& & Ukuran (Ikhsan, 2002) \\
& & Tanda (Ikhsan, 2002) \\
& & Bentuk (Ikhsan, 2002) \\
& & Struktur (Aryanto, 2005) \\
& & Makna (Aryanto, 2005) \\
\hline
\end{tabular}

Hasil analisis dari faktor konfimatori dan Miles dan Huberman adalah:

Tabel 6. Faktor yang mempengaruhi Persepsi

\begin{tabular}{|c|c|c|c|c|}
\hline No & Factor & $\begin{array}{c}\text { People } \\
\text { (Confirmatory } \\
\text { factor } \\
\text { analysis) } \\
\end{array}$ & $\begin{array}{c}\text { Student } \\
\text { (Confirmatory } \\
\text { factor } \\
\text { analysis) } \\
\end{array}$ & $\begin{array}{c}\text { Expert } \\
\text { (Miles and } \\
\text { Huberman } \\
\text { Model) }\end{array}$ \\
\hline \multicolumn{5}{|l|}{ Internal } \\
\hline 1 & $\begin{array}{l}\text { Keakraban dengan } \\
\text { kondisi lingkungan }\end{array}$ & 0,835 & 0,787 & 5 \\
\hline 2 & $\begin{array}{l}\text { Pembelajaran } \\
\text { persepsi }\end{array}$ & 0,769 & 0,585 & 8 \\
\hline 3 & $\begin{array}{l}\text { Motivasi dan } \\
\text { kebutuhan }\end{array}$ & 0,488 & 0,597 & 2 \\
\hline \multicolumn{5}{|c|}{ Eksternal } \\
\hline 1 & Kekuatan tujuan & 0,708 & - & 3 \\
\hline 2 & Posisi objek & 0,665 & 0,686 & 6 \\
\hline 3 & Warna & - & 0,615 & - \\
\hline 4 & Ukuran & 0,577 & 0,658 & 6 \\
\hline 5 & Tanda & - & - & - \\
\hline 6 & Bentuk & 0,804 & 0,705 & 8 \\
\hline 7 & Struktur & 0,647 & - & 4 \\
\hline 8 & Makna & 0,713 & 0,678 & 7 \\
\hline
\end{tabular}


Berdasarkan Tabel 5, dapat dilihat bahwa variabel yang paling berpengaruh untuk golongan masyarakat adalah keakraban dengan kondisi lingkungan dan bentuk. Variabel yang paling berpengaruh untuk golongan mahasiswa adalah keakraban dengan kondisi lingkungan dan bentuk. Variabel yang paling berpengaruh untuk golongan ahli dalam mengidentifikasi Citra Kawasan bersejarah adalah pembelajaran persepsi dan bentuk.

\subsubsection{Hubungan faktor internal-eksternal dengan tipologi persepsi}

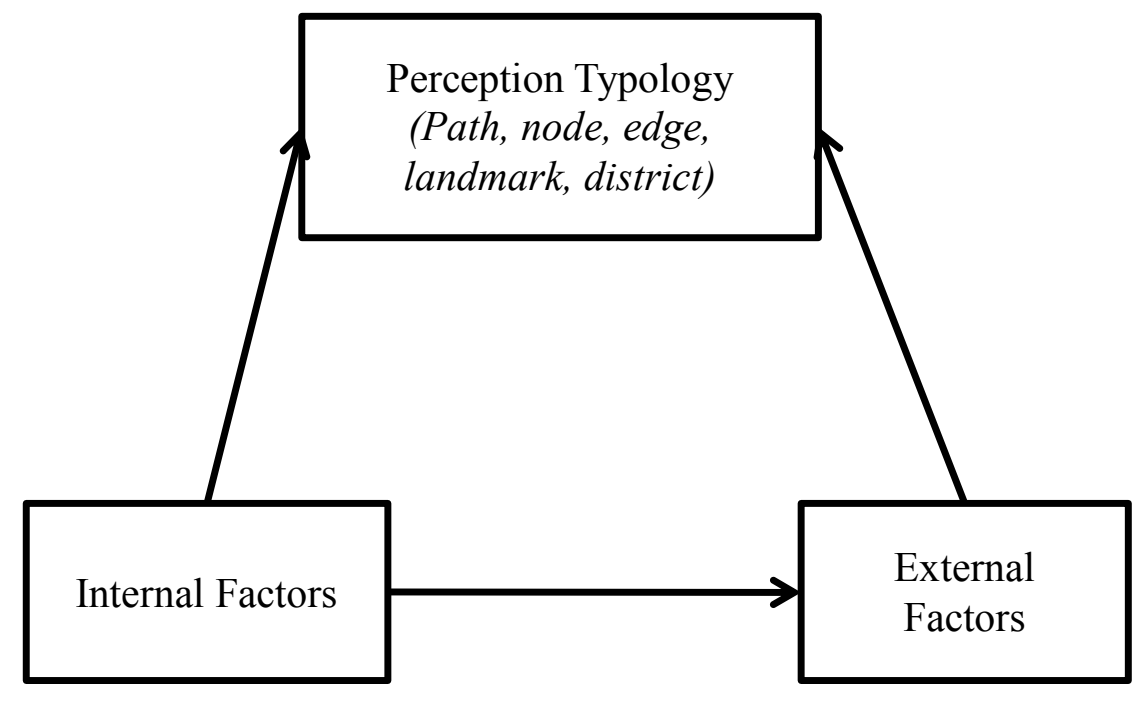

\section{Gambar 12. Hubungan Faktor Internal-Eksternal dengan Tipologi Persepsi}

Berdasarkan skema dapat dilihat bahwa faktor internal, eksternal, dan tipologi persepsi memiliki hubungan dalam mengidentifikasi elemen pembentuk citra kawasan bersejarah. Hubungan antara faktor internal, eksternal, dan tipologi tidak lepas dari variable-variabel yang ada. Hal ini dapat dilihat dari munculnya Jl Kayutangan-Jl Pasar Besar sebagai elemen path; perempatan Kayutangan dan Kawasan Alun-alun Merdeka sebagai node; serta Masjid Jami' dan Alun-alun Tugu sebagai landmark. Seseorang akan mudah mengidentifikasi elemen-elemen tersebut karena keakraban dengan kondisi lingkungan, memiliki pengetahuan tentang sejarah, dan memiliki motivasi dan kebutuhan. Faktor internal tersebut akan mendorong seseorang untuk melihat karakter fisik yang mudah diingat dan dikenali. Karakter fisik dipengaruhi oleh kekuatan tujuan, posisi objek, warna, ukuran, bentuk, struktur, dan makna. Karakter fisik yang dimiliki oleh masing-masing elemen akan membentuk suatu tipologi persepsi yang dapat ditinjau dari teori gestalt. Hubungan antar 3 komponen ini juga didukung oleh teori yang dijelaskan oleh Sudrajat (Purwanto, 2001)yang menyebutkan bahwa hubungan timbale balik manusia dengan lingkungan perkotaan merupakan proses dua arah yang saling terkait, didukung oleh ciri-sifat yang dapat memberikan citra lingkungan, maupun kejiwaan manusia.

\section{Kesimpulan}

Berdasarkan hasil pembahasan pada bab sebelumnya mengenai Citra Kawasan Bersejarah di Pusat Kota Malang, maka dapat disimpulkan bahwa: 
1. Persepsi mengenai citra kawasan bersejarah di pusat kota (Kec. Klojen) masih memiliki perbedaan. Hal ini menunjukkan bahwa citra kawasan bersejarah masih belum bisa ditangkap dengan baik oleh penduduk Kota Malang. Adanya perbedaan persepsi oleh ketiga golongan ini dipengaruhi oleh latar belakang masing-masing golongan.

Berdasarkan prosentase frekuensi kemunculan yang disebutkan oleh total responden menunjukkan bahwa elemen yang sama dari ketiga golongan frekuensi kemunculannya lebih dari 50\%, maka Kecamatan Klojen dapat disebut dengan place.

2. Faktor yang paling mempengaruhi masyarakat dalam mengidentifikasi citra kawasan bersejarah di Kecamatan Klojen adalah faktor keakraban kondisi lingkungan dan bentuk arsitektur. Faktor yang paling mempengaruhi golongan mahasiswa adalah keakraban dengan kondisi lingkungan dan bentuk, sedangkan faktor yang paling mempengaruhi golongan para ahli adalah pembelajaran persepsi dan bentuk. Terdapat hubungan antara faktor internal, eksternal, dan tipologi persepsi dalam mengidentifikasi citra kawasan bersejarah. Faktor internal mempengaruhi faktor eksternal, dan dari faktor eksternal menjadi tipologi persepsi.

\section{Daftar Pustaka}

Aryanto, A., Wahid, J., Aulia, D.N., \& Suriadi, A. 2005. Kajian Pembentukan Citra Kawasan Perumahan Studi Kasus: Perumahan Taman Setiabudi Indah, Medan. Jurnal Arsitektur "ATRIUM". Vol. 02, No. 02 :1-8.

Bell, P.A., Greence, T.C., Fisher, J.D., \& Baum, A. 2001. Environmental Psychology. Orlando: Harcourt College.

Damayanti, R. \& Handinoto. 2005. Pengaruh Gaya Hidup Terhadap Persepsi Kota Surabaya. http://fportfolio.petra.ac.id/user files/98-034/paper-A31-RULLY.pdf. (diakses 16 Desember 2011).

Halim, D. 2005. Psikologi Arsitektur. Jakarta: PT Gramedia Indonesia.

Handinoto. 2010. Arsitektur dan Kota-kota di Jawa pada Masa Kolonial. Surabaya: Graha Ilmu.

Ikhsan, F.A., Haryadi \&Wijono, D. 2002. Elemen dan Struktur Lingkungan Fisik Kota Surakarta: Kajian Peta Mental Warga Kota. Teknosains 15(2), Mei 2002.

Munir, A.R. 2005. Aplikasi Analisis Faktor untuk Persamaan Stimulan dengan SPSS 12. Laboratorium Kompetensi Manajemen Fakultas Ekonomi Unhas.

Purwanto, E. 2001. Pendekatan Pemahaman Citra Lingkungan Perkotaan (melalui kemampuan peta mental pengamat). Dimensi Teknik Arsitektur. 29, (1): 85-92.

Sarwono, S.W. 1992. Psikologi Lingkungan. Jakarta: Rasindo.

Sugiyono. 2011. Metode Penelitian Kombinasi (Mixed Methods). Bandung: Alfabeta. 